\title{
A Comparison of the Use of Physical and Mental Health Services by Homeless People With Severe Mental Health Problems in the Moncton Area Through the At Home/Chez Soi Program
}

\author{
[La version française suit.] \\ Sarah Pakzad, Paul-Émile Bourque, and Jimmy Bourque \\ Université de Moncton \\ Tim Aubry \\ University of Ottawa \\ Lise Gallant, Stefanie R. LeBlanc, and John Tivendell \\ Université de Moncton
}

Sarah Pakzad, School of Psychology, Université de Moncton; Paul-Émile Bourque, School of Psychology, Université de Moncton; Jimmy Bourque, Faculty of Education and Centre of Research and Development in Education, Université de Moncton; Tim Aubry, School of Psychology and Centre for Research on Educational and Community Services, University of Ottawa; Lisa Gallant, Faculty of Health Sciences and Community Services, Université de Moncton; Stefanie R. LeBlanc, Centre of Research and Development in Education, Université de Moncton; John Tivendell, School of Psychology, Université de Moncton.

We thank Jayne Barker (2008-11), Cameron Keller (2011-12), and Catharine Hume (2012-present), Mental Health Commission of Canada At Home/Chez Soi National Project Leads, Paula Goering, National Research Lead, the National Research Team, the five site research teams, the Site Coordinators, and the numerous service and housing providers, as well as persons with lived experience, who have contributed to this project and the research. This research project was made possible by the financial contribution of Health Canada to the Mental Health Commission of Canada. The Mental Health Commission of Canada managed the development and implementation of the study and provided training and technical support to the teams of practitioners and the teams of researchers involved in the project. The opinions expressed are those of the authors only. Tim Aubry (co-author) and Jimmy Bourque (co-author and statistician) had full access to all the data in the study and assumed responsibility for data integrity and data analysis accuracy.

The authors report no conflict of interest.

Correspondence concerning this paper should be addressed to Sarah Pakzad, Université de Moncton, Moncton Campus, Pavillon Léopold-Taillon, 18 Antonine-Maillet Avenue, Moncton, NB E1A 3E9; telephone: (506) 858-4245; fax: (506) 858-4768; email: sarah.pakzad@umoncton.ca 


\begin{abstract}
The At Home / Chez Soi demonstration project was conducted to investigate the effectiveness of the Housing First model in 5 Canadian cities. Using a randomized controlled trial design, this study evaluates the impact of this project on the use of health services by people with severe and persistent mental health problems and a history of homelessness in the greater Moncton area. The sample comprised 193 homeless persons, 95 in the control group and 98 in the treatment group. The results show a significant difference between the 2 groups only in the number of days of hospitalization, particularly in the psychiatric unit. Factors associated with the use of health services by people who are homeless and who have severe mental health problems need to be further investigated.
\end{abstract}

Keywords: homelessness, health services, severe mental illness, mental health

\title{
RÉSUMÉ
}

Le projet At Home / Chez Soi fut conçu afin d'évaluer l'efficacité du modèle Logement d'abord dans 5 villes canadiennes. Utilisant un devis expérimental, la présente étude examine l'effet du programme d'intervention At Home / Chez Soi sur le recours aux services de santé par des personnes itinérantes de la région de Moncton qui ont des troubles psychiatriques sévères et persistants. L'échantillon comprend 193 personnes itinérantes, soit 95 dans le groupe témoin et 98 dans le groupe intervention. Les résultats démontrent une différence significative entre les 2 groupes seulement en ce qui concerne le nombre de jours d'hospitalisation, en particulier à l'unité psychiatrique. Les facteurs associés au recours aux services de santé mentale par les personnes itinérantes ayant des problèmes sévères de santé mentale doivent être étudiés plus à fond.

Mots clés : personnes itinérantes, services de santé, problèmes sévères de santé mentale

Chronic homelessness is often associated with physical and mental health conditions such as psychiatric, somatic, physical, and comorbid disorders, resulting in an increased mortality rate in this vulnerable population (Baggett et al., 2013; Forchuk, Brown, Schofield, \& Jensen, 2008; Hwang et al., 2011; Nusselder et al., 2013). In response to attempts to reduce chronic homelessness in Canada for people with mental health problems, the Mental Health Commission of Canada launched the At Home / Chez Soi demonstration project (Goering et al., 2011). The purpose of this national initiative is to examine the impact of a Housing First strategy for homeless people with severe and persistent mental health problems in five cities across Canada: Moncton, Montreal, Toronto, Winnipeg, and Vancouver. This study attempts to describe the effects of the At Home / Chez Soi demonstration project's Housing First-style intervention on the use of health services by homeless people in the Moncton area. The Moncton site was chosen because the city of 139,000 is the only officially bilingual Canadian urban centre. Moreover, although this site has proportionally fewer homeless people than other large Canadian sites, access to health services for this population is particularly difficult.

In general, homeless people use health services at much higher rates than the general population (Hwang et al., 2013). In particular, they are more likely to visit hospital emergency rooms and to be hospitalized for physical and psychiatric health problems (Hwang et al., 2013). Several other studies indicate that homeless adults with mental health disorders typically underuse preventive mental and physical health services (Baggett, O’Connell, Singer, and Rigotti, 2010: Hahm \& Segal, 2005). Homeless people rarely use mental 
health services, with priority being given to physical health (Bhui, Shanahan, \& Harding, 2006). In addition, variations in the use of health services were also noted according to the typologies of homeless people in a study conducted by Aubry, Klodawsky, and Coulombe (2012).

Literature reviews that evaluate housing and intervention programs for homeless people with mental health problems reveal significant reductions in homelessness and days of hospitalization compared to those receiving more typical treatment in the community (Aubry, Ecker, \& Jetté, 2014; Nelson, Aubry, \& Lafrance, 2007; Rog et al., 2014). Specifically, people living in ordinary housing while receiving intensive follow-up in the community reported having spent less time in hospitals than those who participate in regular programs, those who transition to ordinary housing after having stabilized their ability to function (Gulcur, Stefancic, Shinn, Tsemberis, \& Fischer, 2003), those who receive intensive support in the community without housing, and those who receive the usual services (O’Connell, Kasprow, \& Rosenheck, 2008).

A study of the effect of a housing program that includes a follow-up service in the community among homeless people has shown that the use of health services increases during initial program participation (Mares \& Rosenheck, 2011). However, as community integration improves, the use of services decreases. It should be noted that this study did not include a control group and that follow-up was only for 12 months. In addition, access to health and housing services is associated with improvements in the number of days housed but does not necessarily improve substance use problems, health status, and community integration among the homeless in comparison with a control group receiving the usual services (Mares \& Rosenheck, 2011). On the other hand, homeless people with mental health problems who have undergone an intensive housing program have significantly reduced their use of shelters, length of hospitalization, and time spent in custody (Culhane, Metraux, \& Hadley, 2002). However, the reduction in hospital admissions is offset by increased use of social and community health services (Nelson et al., 2007).

Various literature reviews have documented the effectiveness of the Housing First approach as a model for intervention. Intensive follow-up programs that accompany housing are promising in helping homeless people with mental health problems (Leff et al., 2009; Nelson, 2010; Nelson et al., 2007). According to other recent literature reviews of the Housing First model, the effects of this approach are moderate and the complete body of studies shows methodological limitations (Groton, 2013, Rog et al., 2014). For example, results to date have generally been obtained from studies of relatively small samples from large American cities (Aubry, Ecker et al., 2014).

Goering et al. (2011) undertook a Canadian study of five intervention sites to assess the impact of a hybrid model of Housing First and intensive community monitoring of homeless people with mental health problems. The national results of this pan-Canadian project, At Home / Chez Soi, show that compared to the control group, the Housing First group had fewer emergency room and hospital outpatient visits over a 24-month period (Goering et al., 2014). The purpose of this study is to identify the effects of the Housing First model on the use of specific health services (hospital outpatient services, emergency room visits, hospitalizations, psychiatric unit hospitalizations) by homeless people with severe and chronic mental health problems in Moncton, the smallest city of the five sites. 


\section{METHODOLOGY}

\section{Participants}

Participants in this study included 193 homeless people with severe and chronic mental health problems recruited in the Moncton area as part of the At Home / Chez Soi project. The mean age was 40.2 years $(S D=10.7)$ for the control group and 39.5 years $(S D=11.7)$ for the treatment group. In terms of sex, 61 men and 34 women were in the control group, while the treatment group consisted of 65 men and 33 women. In the Moncton site final report, the Moncton sample is similar to other sites in the national sample in terms of sex, age, and proportion of participants with high needs (Aubry, Bourque, et al., 2014). In Moncton, there is a lower proportion of absolutely homeless participants (56\%) than in the national sample (82\%). Characteristics of the participants are shown in Table 1.

Table 1

Breakdown of Frequencies and Percentages of Sociodemographic Data and Mental Health Issues by CG and TG at Pretest $(N=193)$

\begin{tabular}{lccccc}
\hline & CG $(n=95)$ & & TG $(n=98)$ & \multirow{2}{*}{$\chi^{2}$} \\
\cline { 2 - 3 } & Frequency & $\%$ & Frequency & $\%$ & \\
\hline Sex & & & & & 13.88 \\
$\quad$ Male & 61 & 64 & 65 & 66 & -- \\
$\quad$ Female & 34 & 36 & 33 & 33 & -- \\
Education level & & & & & 16.26 \\
$\quad$ Completed or undertook postsecondary education & 15 & 16 & 22 & 22 & -- \\
$\quad$ Completed high school & 24 & 25 & 21 & 21 & -- \\
$\quad$ Did not complete high school & 56 & 59 & 55 & 55 & -- \\
Mental health problems & & & & & \\
Depression & 72 & 76 & 64 & 65 & 2.87 \\
PTSD & 46 & 48 & 43 & 43 & 0.49 \\
Psychosis & 22 & 23 & 22 & 22 & 0.02 \\
Suicidal ideation & & & & & $8.68^{*}$ \\
$\quad$ None & 7 & 7 & 9 & 9 & -- \\
$\quad$ Weak & 37 & 39 & 34 & 34 & -- \\
$\quad$ Moderate & 16 & 17 & 33 & 33 & -- \\
$\quad$ High & 35 & 37 & 23 & 23 & -- \\
Addiction & & & & & \\
Alcohol & 30 & 32 & 21 & 31 & 0.00 \\
Drugs & 49 & 52 & 55 & 56 & 0.31 \\
\hline
\end{tabular}

$\mathrm{CG}=$ Control Group; $\mathrm{TG}=$ Treatment Group; PTSD $=$ Post-Traumatic Stress Disorder; $*=p<0.05$ 


\section{Moncton site}

The Moncton site was chosen because of its size, geographical location, and composition. Located in New Brunswick on Canada's east coast, Greater Moncton is a medium-sized urban centre with three distinct cities: Moncton, Dieppe, and Riverview. This bilingual community has about 139,000 inhabitants.

\section{Intervention}

The Housing First model, developed from the Pathways to Housing Inc. approach (Tsemberis, 2010), provides housing for homeless people without conditions of sobriety or participation in treatment. The homeless people who participated in the At Home / Chez Soi project had furnished and subsidized housing at their disposal so that their rent would not exceed $30 \%$ of their allowance. Support for mental and physical health issues was provided by an Assertive Community Treatment (ACT) team, and participants were required to adhere to the terms and conditions of the rental contract.

The ACT model assumes that service users have access to a multidisciplinary clinical team at all times and according to their needs. The number of users per responder is usually 10. In Moncton, the team consisted of two psychiatrists, an administrative services coordinator, an occupational therapist, a nurse, a family caregiver, social workers, a user services coordinator, a clinical nurse, an employability services coordinator, and a peer support specialist. The client/staff ratio was 10:1. For their part, those who were assigned to the control group benefited from preexisting services and programs in the region, such as shelters, addiction services, health services, and social services. These participants could receive housing support services and community support services without being part of the Housing First program.

\section{Instruments}

The measurement instruments used in this study were adapted from previously validated scales (Macnaughton, Goering, \& Nelson, 2012). The psychometric properties of the instruments used prove to be adequate (Goering et al., 2011). Demographic variables include age, sex, and level of education (primary, some secondary, secondary, postsecondary).

The Mini International Neuropsychiatric Interview 6.0 (MINI) (Lecrubier et al., 1997) was used to describe the psychiatric condition of participants at the entry point. Research assistants who received prior training on the instruments used for the study administered the MINI. The absence or presence of a diagnosis was used to determine the prevalence of psychiatric disorders in the sample.

Health Services Access Items (ACC) (Hwang et al., 2010) assesses access to health services using three items and includes the following services: family physician and consultation or as-needed care service such as a community health clinic. Cumulative positive responses made up the measure of access to health services in this study, with a high score indicating better access.

The Comorbid Conditions Questionnaire (CMC) is used to identify participants' physical health and chronic conditions. Specifically, the CMC determines the presence or absence of specific health problems. The CMC includes elements from similar instruments: the Canadian Community Health Survey (Statistics Canada, 2014), the National Population Health Survey (Statistics Canada, 2012), and other tools (Mares 
$\&$ Rosenheck, 2007). The score for this instrument represents the cumulative number of physical health problems and chronic diseases (such as diabetes, asthma, or arthritis). The Homelessness Severity Index (HSI) reflects the total number of months of homelessness during the lives of participants (Dickey, Latimer, Powers, Gonzalez, \& Goldfinger, 1997) and was used as a measure of severity of homelessness.

Four measures of the use of health services were used as dependent variables. The four dependent variables include hospital outpatient services (HOS), emergency rooms (ER), hospitalizations (HSP), and hospitalizations in a psychiatric unit (HSP-P). The use of HOS is measured by the number of times the person used hospital outpatient services in the past 6 months without staying overnight and excludes emergency room visits and visits for routine tests. Use of ER is the number of times participants have used these services in the past 6 months. HSP includes the number of days a person has been hospitalized in the past 6 months, and HSP-P is the number of days a patient was hospitalized in the psychiatric unit of a hospital during the past 6 months.

\section{Procedure}

The university hospital and the national coordination centre of the At Home / Chez Soi project both granted ethical approval (Goering et al., 2011), as did he universities and health institutions where the researchers involved in the five demonstration sites work. The At Home / Chez Soi project is registered with the International Standard Randomized Control Trial Number Register and is identified by the code ISRCIN42520374.

Research teams in each of the five project sites administered the measurement tools to the participants over a 2-year period. The Health Diary platform was used for data encoding and storage (Goering et al., 2011). This study focuses only on Moncton site data obtained from follow-up interviews at the pretest and at 6-month, 12-month, 18-month and 24-month intervals.

Participants were recruited initially from shelters and mental health centres in the city of Moncton. A toll-free telephone line was also used to allow individuals to self-refer. Community agencies and mental health services in the Moncton area could also refer participants to the project. The research team then met with the participants in shelters, hospitals, and public places offering a certain level of privacy. They met those participants who had temporary living arrangements in the community in their homes to explain the At Home / Chez Soi project. The team obtained consent from those wishing to participate and conducted an assessment of their eligibility.

Members of the research team received specific training on the project protocol and administration of the questionnaires in order to standardize the collection of data. The inclusion criteria for the study were: 18 years of age or older; homeless or precariously housed, i.e., in a single room, rooming house, hotel or motel; and suffering from a severe mental health disorder according to the MINI assessment, which specifically targeted DSM-IV axis I disorders (American Psychiatric Association, 1994).

A team member then met with the eligible and consenting candidates to administer the pretest questionnaires. Eligible participants were then randomly assigned to the treatment group and the control group at a 1:1 ratio (Aubry, Bourque et al., 2014). This breakdown into groups was determined by the data encoding service using a suitable algorithm, and the result was revealed to the participants at the end of the 
interview. Participants and interviewers were therefore not blind to the composition of the groups. Participants committed to respond to these same questionnaires every 6 months for the duration of their participation, i.e., after $6,12,18$, and 24 months. The questions were read to all participants in order to standardize the administration of the questionnaires. A small financial compensation was offered in recognition of their participation. Details of the At Home / Chez Soi project protocol are presented in Goering et al. (2011).

\section{Statistical analysis}

In this study, comparisons were made between the time progression of the control group and the treatment group for all variables under study using mixed-model variance analyses on each service, i.e., HOS, ER, HSP, and HSP-P. A dummy variable (Event) was created to identify the five measurement times, while the membership group (control or treatment) was the independent variable (Group) in the four models. Special attention was paid to the interaction effect Event $x$ Group to determine whether use of the four different types of services progressed differently over time in the two groups. Since the set of dependent variables proved to be strongly asymmetric using a zero mode, a negative binomial distribution was postulated. Statistical analyses were carried out using the 22nd version of the Statistical Package for Social Sciences (SPSS) software. All analyses were done according to intent to treat, that is, each statistical unit was analyzed according to the group to which it was randomized.

\section{RESULTS}

The profile of sociodemographic variables and mental health problems is presented in Table 1. The results of this research demonstrate that there are no statistically significant differences between the two groups with respect to mental health problems except for the suicidal ideation variable, $\chi^{2}(3)=8.68, p<$ 0.05 . The adjusted standardized residues indicate that the control group had a higher rate of suicidal ideation than the treatment group. Furthermore, in Table 2, the results do not show statistically significant differences between the control and treatment groups with respect to access to services, chronic diseases, and severity of homelessness. In general, the results did not reveal any differences between the control and treatment groups continued on $p .11$

Table 2

\section{Means, Standard Deviations, and $t$-Test of Pretest Health Variables for Control Group and Treatment Group $(N=193)$}

\begin{tabular}{lccccc}
\hline & \multicolumn{2}{c}{ Control Group } & \multicolumn{2}{c}{ Treatment Group } & \multirow{2}{*}{$t$} \\
\cline { 2 - 4 } & Mean & SD & Mean & SD & \\
\hline Access to services (ACC) & 1.96 & 0.76 & 1.98 & 0.88 & -0.19 \\
Chronic diseases (CMC) & 6.00 & 3.35 & 5.62 & 3.40 & 0.78 \\
Severity of homelessness (HSI) & 41.74 & 49.52 & 57.85 & 85.93 & 1.57 \\
\hline
\end{tabular}



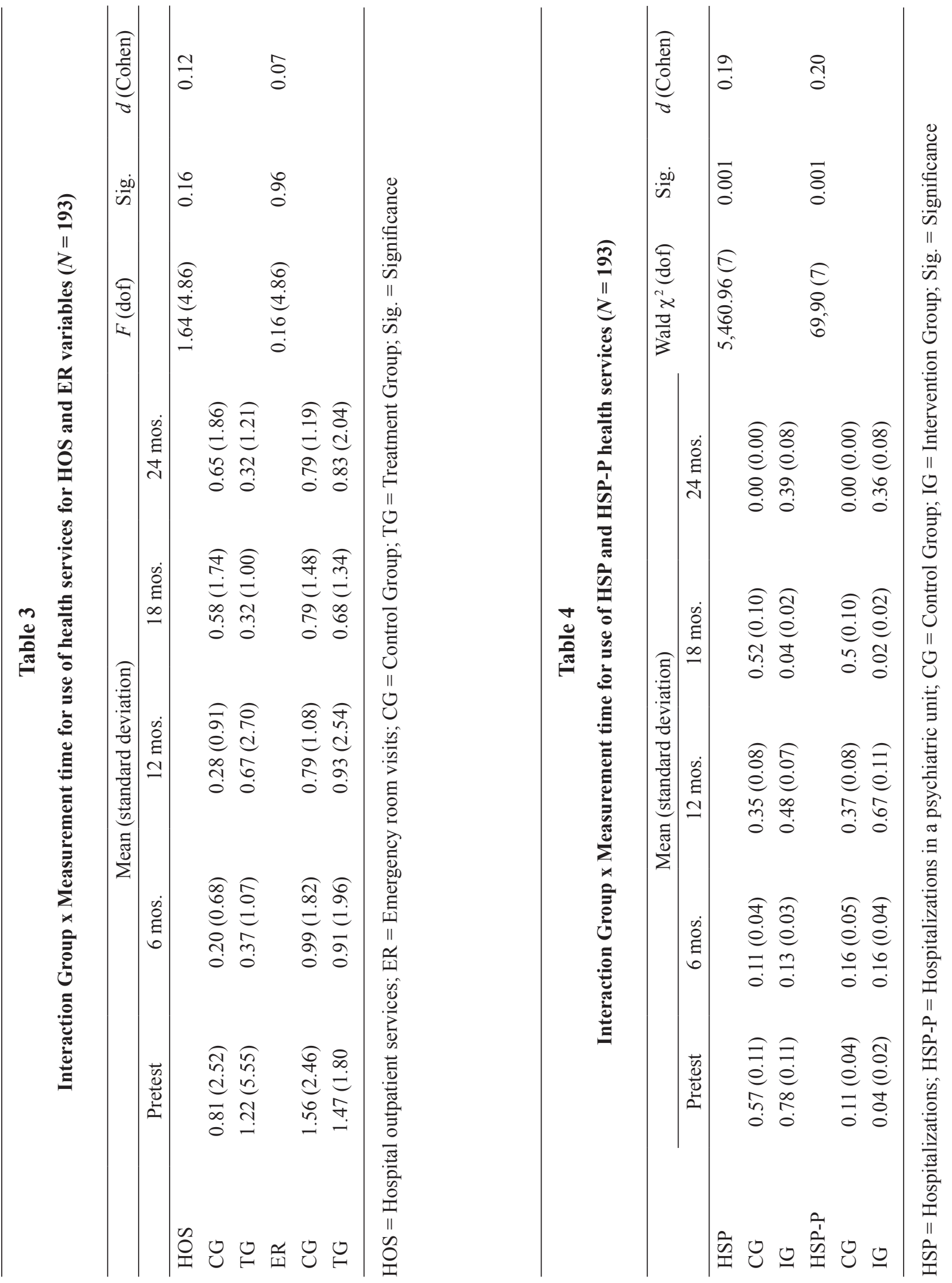
Figure 1

Mean Use of Health Services as a Function of Time $(N=193)$
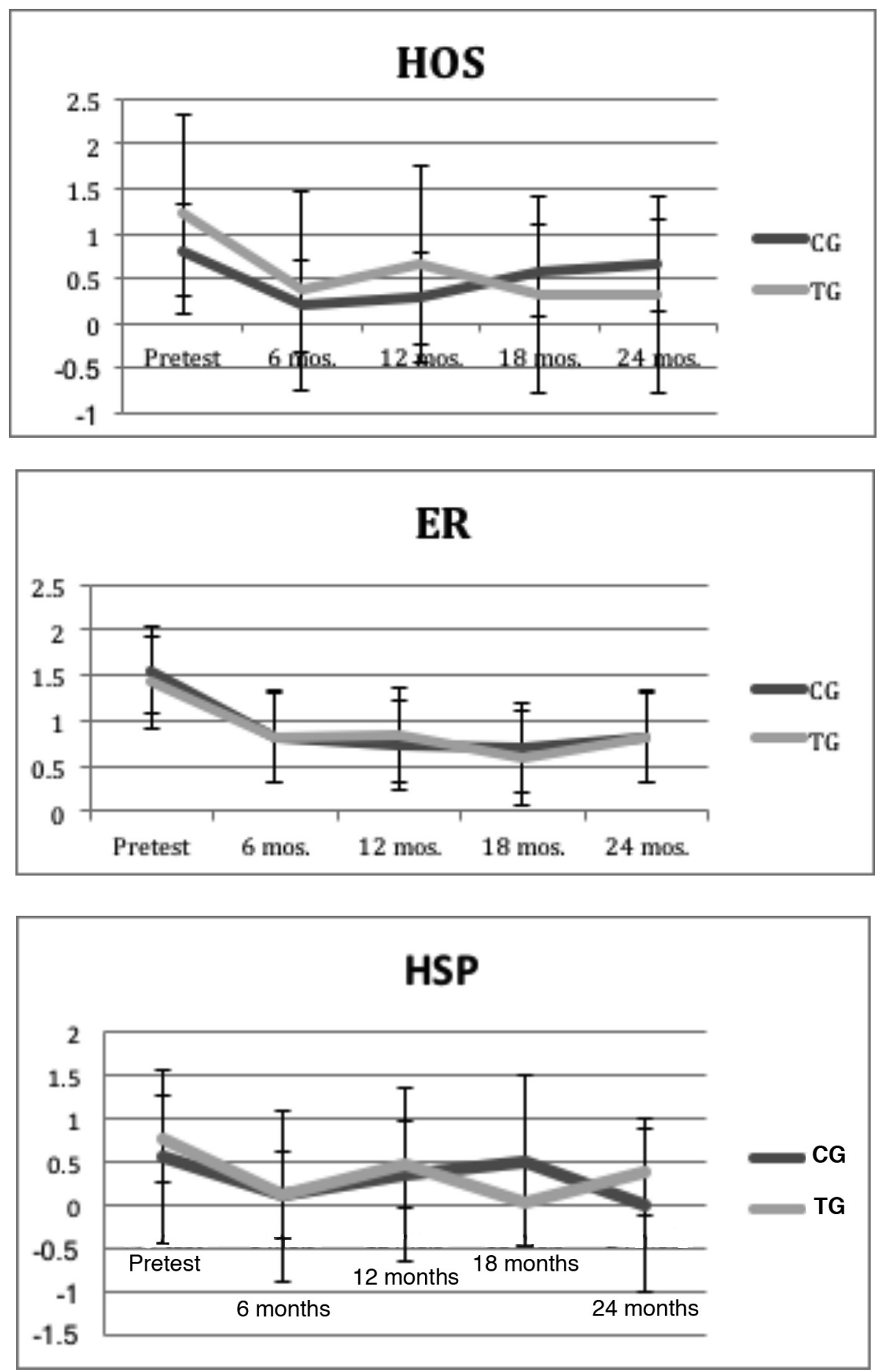

...continued 
Figure 1, continued

Mean Use of Health Services as a Function of Time $(N=193)$

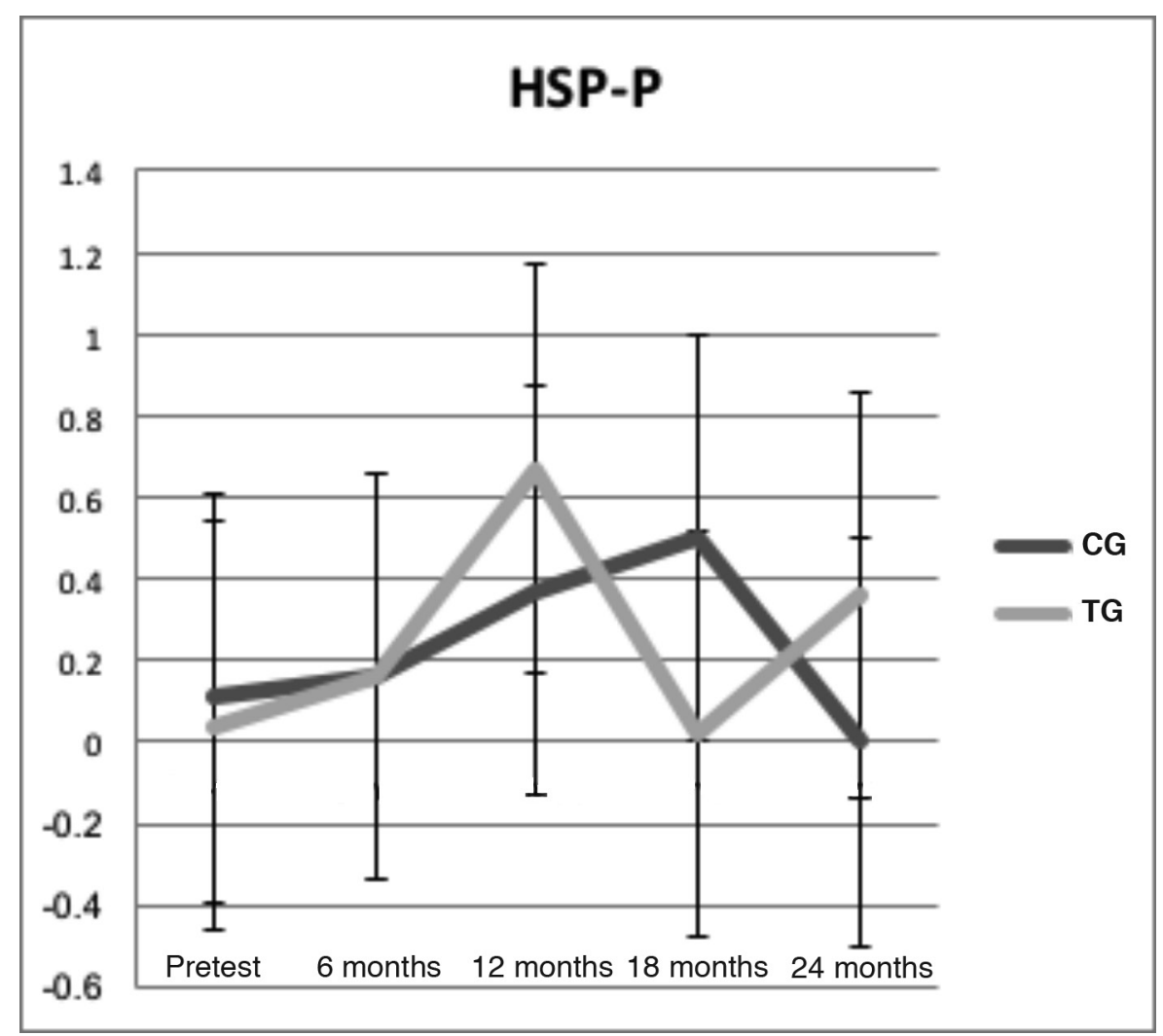

HOS $=$ Hospital outpatient services; ER = Emergency room visits; HSP = Hospitalizations; HSP-P = Hospitalizations in a psychiatric unit; $\mathrm{CG}=$ Control Group; $\mathrm{TG}=$ Treatment Group 
continued from $p .7$

with respect to sociodemographic and health variables. These results confirm that the sampling distribution is equivalent for both groups with respect to most of the variables measured.

Tables 3 and 4 and Figure 1 present the results of the mixed-model variance analysis for the use of health services between groups as a function of time. These findings do not reveal statistically significant differences in the use of HOS and ER between groups as a function of time. The effect sizes, all less than 0.20 in absolute value, are negligible according to Cohen's criterion (1988). However, the results revealed a significant interaction between the group and time in terms of the number of hospital days and the number of days spent in a psychiatric unit. As shown in Table 4, the variation in the number of days of hospitalization and hospitalization in the psychiatric unit differs between the two groups, with a more pronounced decrease after 24 months among those in the treatment group.

\section{DISCUSSION}

In the context of the At Home / Chez Soi project, this study evaluated the impact of a Housing First intervention on the use of hospital outpatient services, emergency room visits, hospital admissions, and hospital admissions to the psychiatric unit by homeless people in the Moncton area with severe and chronic mental health problems. In this regard, the results show that the Housing First intervention did not affect hospital outpatient and emergency room visits. During the project's 24-month follow-up, use of these services decreased, but they did so equally for the control group and the treatment group. On the other hand, the treatment group and the control group exhibited different trajectories over time with respect to rate of hospitalization in the psychiatric unit, concluding with a lower rate of use for the treatment group after 24 months.

These findings are inconsistent with those of Kessell, Bhatia, Bamberger, and Kushel (2006), who found no change in the use of health services between a housing treatment group and a control group. However, as noted by these same authors, rates of use of health services were high, as is the case with the results of this study. It is possible that the nature of intensive follow-up in the community may explain these results. In particular, the fact that participants in the treatment group received community follow-up from a multidisciplinary team that supported them during difficult times may have served to prevent hospitalizations. These findings are consistent with results from a large number of studies of community-based treatment teams (Aubry, Dostaler, \& Baronet, 2004).

Despite the negligible effects observed, this study still serves to document the use of health services by homeless people with severe and chronic mental health problems. As noted in the studies by Mares and Rosenheck (2010) and Wright, Vartanian, Hsin-Fang, Royal, and Matson (2016), use of services decreased after participation in the intervention. However, these two studies did not include a control group. In another study (Martinez \& Burt, 2006), intervention with housing reduces the use of emergency rooms and hospitalization rates for homeless people. In this study, the use of services decreased similarly for the control and treatment groups only for hospital outpatient and emergency room visits. So there seems to be a differential effect depending on the nature of the intensive follow-up in the community and the duration of the intervention. 
Moreover, the characteristics of homeless people in the Moncton area indicate that they are mostly people suffering from post-traumatic stress disorder, who rely less on hospital outpatient services compared with homeless people with a different diagnosis (Pakzad et al., 2015). In addition, women are more likely to use social and community services. It is possible that the participants in this study were referred to the program during a difficult period in their lives and we can predict that they will improve and return to more stable functioning over time.

The difference between the results of this study and those of Martinez and Burt (2006) can be explained by the fact that they used administrative data from medical records rather than self-reported data. It should be noted that the Moncton site initially had lower use of health services than the other At Home / Chez Soi project sites (Aubry, Bourque et al., 2014). The scarcity of such services in comparison with the other major cities participating in the study and the difficulty of access to the services available to this population could be factors. There is little use of mental health services by homeless people, suggesting that the focus is more on physical health than on mental health (Bhui et al., 2006).

Some limitations inherent in this study need to be highlighted. First, the sample size was small for the model that was used. In addition, it was not necessarily representative of other rural or metropolitan areas in the country. However, there are few scholarly papers dealing with housing programs in small towns. This study could potentially be included in a meta-analysis to help assess the impact of such interventions. In addition, no information was available on participants' medical records to verify the duration and number of hospital stays and use of emergency services.

\section{CONCLUSION}

The findings of this study point to some conclusions regarding the use of health services by homeless people. To increase our understanding of these findings, we need more in-depth analyses using administrative data to better identify the factors associated with the use of health services by homeless people. However, it is common for homeless people to use social and community services more than specialized mental health services (Bhui et al., 2006). It would be important to better understand the reasons, attitudes, and obstacles that influence homeless people's use of mental health services.

\section{REFERENCES}

American Psychiatric Association. (1994). Diagnostic and statistical manual of mental disorders (4th ed.). Washington, DC: Author.

Aubry, T., Bourque, J., Volk, J., Leblanc, S., Nolin, D., \& Jetté, J. (2014). At Home / Chez Soi project: Moncton final report. Calgary, AB: Mental Health Commission of Canada.

Aubry, T., Dostaler, T., \& Baronet, A.-M. (2004). Revue des études empiriques sur l'efficacité du suivi communautaire. In R. Emard \& T. Aubry (Eds.), Le suivi communautaire en santé mentale : une invitation à bâtir sa vie (pp. 129-202). Ottawa, ON: University of Ottawa Press.

Aubry, T., Ecker, J., \& Jetté, J. (2014). Supported housing as a promising Housing First approach for people with severe and persistent mental illness. Dans M. Guirgis-Younger, R. McNeil, \& S. W. Hwang (dir.), Homelessness $\&$ health in Canada (pp. 155-188). Ottawa, ON: University of Ottawa Press.

Aubry, T., Klodawsky, F., \& Coulombe, D. (2012). Comparing the housing trajectories of different classes within a diverse homeless population. American Journal of Community Psychology, 49(1-2), 142-155. 
Baggett, T. P., Hwang, S. W., O’Connell, J. J., Porneala, B. C., Stringfellow, E. J., Orav, E. J., . . Rigotti, N. A. (2013). Mortality among homeless adults in Boston: Shifts in causes of death over a 15-year period. JAMA Internal Medicine, 173, 189-195.

Baggett, T. P., O’Connell, J. J., Singer, D. E., \& Rigotti, N. A. (2010). The unmet health care needs of homeless adults: A national study. American Journal of Public Health, 100, 1326-1333.

Bhui, K., Shanahan, L., \& Harding, G. (2006). Homelessness and mental illness: A literature review and a qualitative study of perceptions of the adequacy of care. International Journal of Social Psychiatry, 52(2), 152-165.

Cohen, J. (1988). Statistical power analysis for the behavioral sciences (2nd ed.). Hillsdale, NJ: Lawrence Erlbaum Associates.

Culhane, D. P., Metraux, S., \& Hadley, T. (2002). Public service reductions associated with placement of homeless persons with severe mental illness in supportive housing. Housing Policy Debate, 13(1), 107-163.

Dickey, B., Latimer, E., Powers, K., Gonzalez, O., \& Goldfinger, S. M. (1997). Housing costs for adults who are mentally ill and formerly homeless. Journal of Mental Health Administration, 24(3), 291-305.

Forchuk, C., Brown, S. A., Schofield, R., \& Jensen, E. (2008). Perception of health and health service utilization among homeless and housed psychiatric consumers/survivors. Journal of Psychiatric and Mental Health Nursing, 15(5), 399-407.

Goering, P. N., Streiner, D. L., Adair, C., Aubry, T., Barker, J., Distasio, J., \& Zabkiewicz, D. M. (2011). The At Home / Chez Soi trial protocol: A pragmatic, multi-site, randomized controlled trial of a Housing First intervention for homeless individuals with mental illness in five Canadian cities. British Medical Journal Open, 1(2). doi:10.1136/bmjopen-2011-000323

Goering, P., Veldhuizen, S., Watson, A., Adair, C., Kopp, B., Latimer, E., \& Aubry, T. (2014). National At Home / Chez Soi final report. Calgary, AB: Mental Health Commission of Canada.

Groton, D. (2013). Are Housing First programs effective? A research note. Journal of Sociology and Social Welfare, 40(1), 51-63.

Gulcur, L., Stefancic, A., Shinn, M., Tsemberis, S., \& Fischer, S. N. (2003). Housing, hospitalization, and cost outcomes for homeless individuals with psychiatric disabilities participating in continuum of care and Housing First programmes. Journal of Community \& Applied Social Psychology, 13(2), 171-186.

Hahm, H. C., \& Segal, S. P. (2005). Failure to seek health care among the mentally ill. American Journal of Orthopsychiatry, 75(1), 54-62.

Hwang, S. W., Aubry, T., Palepu, A., Farrell, S., Nisenbaum, R., Hubley, A., \& Chambers, C. (2011). The health and housing in transition study: A longitudinal study of the health of homeless and vulnerably housed adults in three Canadian cities. International Journal of Public Health, 56, 609-623.

Hwang, S. W., Chambers, C., Chiu, S., Katic, M., Kiss, A., Redelmeier, D. A., \& Levinson, W. (2013). A comprehensive assessment of health care utilization among homeless adults under a system of universal health insurance. American Journal of Public Health, 103(Suppl. 2), S294-S301.

Hwang, S. W., Ueng, J. J., Chiu, S., Kiss, A., Tolomiczenko, G., Cowan, L., . . Redelmeier, D. A. (2010). Universal health insurance and health care access for homeless persons. American Journal of Public Health, 100(8), 1454-1461.

Kessell, E. R., Bhatia, R., Bamberger, J. D., \& Kushel, M. B. (2006). Public health care utilization in a cohort of homeless adult applicants to a supportive housing program. Journal of Urban Health, 83(5), 860-873.

Lecrubier, Y., Sheehan, D.V., Weiller, E., Amorim, P., Bonora, I., Sheehan K, . . Dunbar, G. (1997). The Mini International Neuropsychiatric Interview (MINI): A short diagnostic structured interview: Reliability and validity according to the CIDI. European Psychiatry, 12(5), 224-231.

Leff, H. S., Chow, C. M., Pepin, R., Conley, J., Allen, I. E., \& Seaman, C. A. (2009). Does one size fit all? What we can and can't learn from a meta-analysis of housing models for persons with mental illness. Psychiatric Services, 60, 473-482,

Macnaughton, E. L., Goering, P. N., \& Nelson, G. B. (2012). Exploring the value of mixed methods within the At Home / Chez Soi Housing First project: A strategy to evaluate the implementation of a complex population health intervention for people with mental illness who have been homeless. Canadian Journal of Public Health, 103(7 Suppl. 1), S57-S62. 
Mares, A. S., \& Rosenheck, R. A. (2007). HUD/HHS/VA collaborative initiative to help end chronic homelessness national performance outcomes assessment: Preliminary client outcomes report. West Haven, CT: Northeast Program Evaluation Center.

Mares, A. S., \& Rosenheck, R. A. (2010). Twelve-month client outcomes and service use in a multisite project for chronically homeless adults. Journal of Behavioral Services \& Research, 37(2), 167-183.

Mares, A. S., \& Rosenheck, R. A. (2011). A comparison of treatment outcomes among chronically homelessness adults receiving comprehensive housing and health care services versus usual local care. Administration and Policy in Mental Health and Mental Health Services Research, 38(6), 459-475.

Martinez, T., \& Burt, M. (2006). Impact of permanent supportive housing on the use of acute care health services by homeless adults. Psychiatric Services, 57(7), 992-999.

Nelson, G. (2010). Housing for people with serious mental illness: Approaches, evidence, and transformative change. Journal of Sociology and Social Welfare, 37(4), 123-146.

Nelson, G., Aubry, T., \& Lafrance, A. (2007). A review of the literature on the effectiveness of housing and support, Assertive Community Treatment, and intensive case management interventions for persons with mental illness who have been homeless. American Journal of Orthopsychiatry, 77(3), 350-361.

Nusselder, W. J., Marcel, T., Slockers, M. T., Krol, K., Slockers, C. T., Looman, C. W. N., \& van Beeck, E. F. (2013). Mortality and life expectancy in homeless men and women in Rotterdam: 2001-2010. PLOS ONE, 8(10): e73979.

O’Connell, M. J., Kasprow, W., \& Rosenheck, R. A. (2008). Rates and risk factors for homelessness after successful housing in a sample of formerly homeless veterans. Psychiatric Services, 59, 268-275.

Pakzad, S., Bergheul, S., Jbilou, J., Bourque, J., Ringuette, J., Gallant, L., \& Bourque, P. E. (2015). Le recours aux services de santé, sociaux et communautaires par les personnes itinérantes de la région de Moncton. Canadian Journal of Community Mental Health, 33(4), 91-105.

Rog, D. J., Marshall, T., Dougherty, R. H., George, P., Daniels, A. S., Ghose, S. S., \& Delphin-Rittmon, M. E. (2014). Permanent supportive housing: Assessing the evidence. Psychiatric Services, 65(3), 287-294.

Statistics Canada. (2012). National population health survey: Household component, longitudinal (NPHS). Retrieved from http://www23.statcan.gc.ca/imdb/p2SV.pl?Function=getSurvey\&SDDS=3225

Statistics Canada. (2014). Canadian community health survey-annual component (CCHS). Retrieved from http:// www23.statcan.gc.ca/imdb/p2SV.pl?Function=getSurvey\&SDDS=3226

Tsemberis, S. (2010). Housing First: The pathways model to end homelessness for people with mental illness and addiction. Center City, MN: Hazelden.

Wright, B. J., Vartanian, K. B., Hsin-Fang, L. Royal, N., \& Matson, J. K, (2016). Formerly homeless people had lower overall health care expenditures after moving into supportive housing. Health Affairs, 35, 20-27. 


\title{
Une comparaison du recours aux services de santé physique et mentale par des personnes itinérantes de la région de Moncton ayant des problèmes sévères de santé mentale dans le cadre de l'intervention At Home / Chez Soi
}

\author{
Sarah Pakzad, Paul-Émile Bourque et Jimmy Bourque \\ Université de Moncton \\ Tim Aubry \\ Université d'Ottawa \\ Lise Gallant, Stefanie R. LeBlanc et John Tivendell \\ Université de Moncton
}

\begin{abstract}
Sarah Pakzad, École de psychologie, Université de Moncton; Paul-Émile Bourque, École de psychologie, Université de Moncton; Jimmy Bourque, Faculté des sciences de l'éducation et Centre de recherche et de développement en éducation, Université de Moncton; Tim Aubry, École de psychologie et Centre de recherche sur les services éducatifs et communautaires, Université d'Ottawa; Lise Gallant, Faculté des sciences de la santé et des services communautaires, Université de Moncton; Stefanie R. LeBlanc, Centre de recherche et de développement en éducation, Université de Moncton; John Tivendell, École de psychologie, Université de Moncton.

Nous remercions Jayne Barker (2008-2011), Cameron Keller (2011-2012) et Catharine Hume (2012-présent), directrices et directeur nationaux du projet At Home / Chez Soi de la Commission de la santé mentale du Canada, ainsi que Paula Goering, directrice nationale de la recherche pour le projet, l'équipe nationale de la recherche, les cinq équipes de chercheurs des sites, les coordonnateurs de site et les nombreux fournisseurs de services et de logements, y compris les personnes ayant vécu des expériences qui ont contribué à ce projet. Ce projet de recherche a été rendu possible grâce à la contribution financière de Santé Canada à la Commission de la santé mentale du Canada. La Commission de la santé mentale du Canada a géré le développement et l'implantation de l'étude et assuré la formation et le soutien technique aux équipes d'intervenants et d'intervenantes et aux équipes de chercheurs engagées dans le projet. Les opinions exprimées représentent uniquement celles des auteurs. Tim Aubry (co-auteur) et Jimmy Bourque (co-auteur et statisticien) ont eu un accès complet à toutes les données de l'étude et assument la responsabilité de l'intégrité des données et de la précision de l'analyse des données.
\end{abstract}

Les auteurs ne rapportent aucun conflit d'intérêt. 


\title{
RÉSUMÉ
}

Le projet At Home / Chez Soi fut conçu afin d'évaluer l'efficacité du modèle Logement d'abord dans 5 villes canadiennes. Utilisant un devis expérimental, la présente étude examine l'effet du programme d'intervention At Home / Chez Soi sur le recours aux services de santé par des personnes itinérantes de la région de Moncton qui ont des troubles psychiatriques sévères et persistants. L'échantillon comprend 193 personnes itinérantes, soit 95 dans le groupe témoin et 98 dans le groupe intervention. Les résultats démontrent une différence significative entre les 2 groupes seulement en ce qui concerne le nombre de jours d'hospitalisation, en particulier à l'unité psychiatrique. Les facteurs associés au recours aux services de santé mentale par les personnes itinérantes ayant des problèmes sévères de santé mentale doivent être étudiés plus à fond.

Mots clés : personnes itinérantes, services de santé, problèmes sévères de santé mentale

\begin{abstract}
The At Home / Chez Soi demonstration project was conducted to investigate the effectiveness of the Housing First model in 5 Canadian cities. Using a randomized controlled trial design, this study evaluates the impact of this project on the use of health services by people with severe and persistent mental health problems and a history of homelessness in the greater Moncton area. The sample comprised 193 homeless persons, 95 in the control group and 98 in the treatment group. The results show a significant difference between the 2 groups only in the number of days of hospitalization, particularly in the psychiatric unit. Factors associated with the use of health services by people who are homeless and who have severe mental health problems need to be further investigated.
\end{abstract}

Keywords: homelessness, health services, severe mental illness, mental health

L'itinérance chronique est souvent associée à des conditions de santé physique et mentale comme des troubles psychiatriques, somatiques, physiques et de comorbidité élevée, augmentant ainsi le taux de mortalité chez cette population vulnérable (Baggett et al., 2013; Forchuk, Brown, Schofield et Jensen, 2008; Hwang et al., 2011; Nusselder et al., 2013). En réponse aux tentatives faites pour réduire l'itinérance chronique au Canada chez les personnes ayant des troubles de santé mentale, la Commission de la santé mentale du Canada a lancé le projet de démonstration At Home / Chez Soi (Goering et al., 2011). Cette initiative nationale vise à étudier l'effet d'une intervention de type Logement d'abord auprès de personnes itinérantes ayant des troubles sévères et persistants de santé mentale dans cinq villes au Canada, soit Moncton, Montréal, Toronto, Winnipeg et Vancouver. La présente étude cherche à décrire les effets de l'intervention Logement d'abord du projet de démonstration At Home / Chez Soi sur le recours aux services de santé par des personnes itinérantes de la région de Moncton. Le site de Moncton fut choisi car cette ville de 139000 habitants représente le seul centre urbain canadien officiellement bilingue. De plus, même si, proportionnellement, ce site compte moins de personnes itinérantes que les autres grands sites canadiens, l'accès aux services de santé pour cette population est particulièrement difficile.

La correspondance concernant cet article devrait être acheminée à Sarah Pakzad; Université de Moncton, Campus de Moncton, Pavillon Léopold-Taillon, 18, avenue Antonine-Maillet, Moncton, NB E1A 3E9; téléphone : (506) 858-4245; télécopieur : (506) 858-4768; courriel : sarah.pakzad@umoncton.ca 
De manière générale, les personnes itinérantes ont des taux de recours aux services de santé beaucoup plus élevés que la population générale (Hwang et al., 2013). En particulier, ces personnes sont plus susceptibles de visiter les salles d'urgence des hôpitaux et d'être hospitalisées pour des problèmes de santé physique et psychiatrique (Hwang et al., 2013). Plusieurs autres études indiquent que les adultes itinérants atteints de troubles de santé mentale sous-utilisent généralement les services de santé mentale ou de santé physique préventifs (Baggett, O'Connell, Singer et Rigotti, 2010; Hahm et Segal, 2005). Les personnes itinérantes ont très peu recours aux services de santé mentale, la priorité étant plutôt accordée à la santé physique (Bhui, Shanahan et Harding, 2006). De plus, des variations dans le recours aux services de santé ont également été notées en fonction des typologies des personnes itinérantes dans une étude menée par Aubry, Klodawsky et Coulombe (2012).

Des recensions des écrits portant sur l'évaluation des programmes de logement et d'intervention destinés aux personnes itinérantes ayant des problèmes de santé mentale révèlent des réductions significatives des taux d'itinérance et des jours d'hospitalisation en comparaison aux personnes qui reçoivent les traitements usuels dans la communauté (Aubry, Ecker et Jetté, 2014; Nelson, Aubry et Lafrance, 2007; Rog et al., 2014). Plus précisément, les personnes vivant en logement ordinaire tout en recevant un suivi intensif dans le milieu ont dit avoir passé moins de temps en milieu hospitalier comparativement aux personnes qui participent à des programmes réguliers, à celles qui font la transition vers des logements ordinaires après avoir stabilisé leur fonctionnement (Gulcur, Stefancic, Shinn, Tsemberis et Fischer, 2003), à celles qui ont reçu un soutien intensif dans la communauté sans logement et à celles ayant reçu les services usuels (O'Connell, Kasprow et Rosenheck, 2008).

L'étude de l'effet d'un programme de logement qui comporte un service de suivi dans le milieu chez des personnes itinérantes a démontré que le recours aux services de santé augmente lors de la participation initiale au programme (Mares et Rosenheck, 2011). Cependant, au fur et à mesure que l'intégration dans la communauté s'améliore, le recours aux services diminue. Il est à noter que cette étude n'incluait pas de groupe témoin et que le suivi était seulement pour 12 mois. De plus, l'accès à des services de soins de santé et de logement est associé à des améliorations dans le nombre de jours logés, mais n'améliore pas nécessairement les problèmes de toxicomanie, l'état de santé et l'intégration communautaire chez les personnes itinérantes en comparaison avec un groupe témoin recevant les services usuels (Mares et Rosenheck, 2011). Par ailleurs, les personnes itinérantes ayant des problèmes de santé mentale et qui ont suivi un programme intensif de logement ont réduit de façon significative leur recours aux refuges, la durée des hospitalisations ainsi que le temps d'incarcération (Culhane, Metraux et Hadley, 2002). Toutefois, la réduction des hospitalisations est contrebalancée par une augmentation du recours aux services de santé sociaux et communautaires (Nelson et al., 2007).

Diverses revues de la littérature ont documenté l'efficacité du modèle Logement d'abord comme modèle d'intervention. Ainsi, les programmes de suivi intensif avec logement s'avèrent prometteurs dans l'intervention auprès des personnes itinérantes ayant des problèmes de santé mentale (Leff et al., 2009; Nelson, 2010; Nelson et al., 2007). D'autres recensions récentes d'écrits portant sur le modèle d'intervention Logement d'abord soutiennent que les effets de cette approche sont modérés et que l'ensemble des études démontre des limites au plan méthodologique (Groton, 2013; Rog et al., 2014). Par exemple, jusqu'à présent, les résultats proviennent généralement d'études sur des échantillons relativement petits, qui provenaient des grande villes américaines (Aubry, Ecker et al., 2014). 
Goering et al. (2011) ont entrepris une étude à l'échelle canadienne de cinq sites d'intervention pour évaluer l'impact d'un modèle hybride de Logement d'abord et d'un suivi intensif dans le milieu auprès de personnes itinérantes ayant des problèmes de santé mentale. Les résultats nationaux de ce projet pancanadien, At Home /Chez Soi, démontrent qu'en comparaison au groupe témoin, le groupe du modèle Logement d'abord a eu moins de visites aux salles d'urgence et s'est rendu moins fréquemment aux consultations externes des hôpitaux au cours d'une période de 24 mois (Goering et al., 2014). La présente étude vise à cerner les effets du modèle Logement d'abord sur l'utilisation de services de santé particuliers (services hospitaliers ambulatoires; visites aux salles d'urgence; hospitalisations; hospitalisations à l'unité psychiatrique) par des personnes itinérantes ayant des problèmes sévères et chroniques de santé mentale à Moncton, la plus petite ville des cinq sites.

\section{MÉTHODE}

\section{Participants et participantes}

Les participants et participantes de cette étude sont 193 personnes itinérantes atteintes de problèmes sévères et chroniques de santé mentale, recrutées dans la région de Moncton dans le cadre du projet At Home / Chez Soi. La moyenne d'âge est de 40,2 ans $(E ́=10,7)$ pour le groupe témoin et de 39,5 ans $(E ́ T=11,7)$ pour le groupe intervention. Pour ce qui est du sexe des participants et participantes, 61 hommes et 34 femmes composaient le groupe témoin, tandis que le groupe intervention était formé de 65 hommes et de 33 femmes. Dans le rapport final du site de Moncton, l'échantillon de Moncton est similaire à celui des autres sites de l'échantillon national en termes de sexe, d'âge et de proportion des participants et participantes ayant un niveau élevé de besoins (Aubry, Bourque et al., 2014). À Moncton, il y a une proportion moins élevée de participantes et participants itinérants (56\%) en comparaison avec l'échantillon national (82\%). Les caractéristiques des participants et participantes se trouvent au tableau 1.

\section{Site de Moncton}

Le site de Moncton fut choisi en raison de sa taille, de sa situation géographique et de sa composition. Située au Nouveau-Brunswick, sur la côte est du Canada, la grande région de Moncton est un centre urbain de taille moyenne composé de trois villes distinctes, soit Moncton, Dieppe et Riverview. Cette localité bilingue compte près de 139000 habitants.

\section{Intervention}

Le modèle Logement d'abord, élaboré à partir de l'approche Pathways to Housing Inc. (Tsemberis, 2010), consiste à fournir un logement à des personnes en situation d'itinérance sans conditions relatives à la sobriété ou à la participation au traitement. Les personnes itinérantes qui ont participé au projet At Home / Chez Soi ont eu à leur disposition un logement meublé et subventionné de manière à ce que leur loyer ne dépasse pas $30 \%$ de leur allocation. Un soutien pour des problèmes de santé mentale et physique leur était offert par une équipe de Suivi intensif dans le milieu (Assertive Community Treatment-ACT) et les participants et participantes devaient respecter les modalités du contrat de location de leur logement. 
Tableau 1

Ventilation des fréquences et des pourcentages des données sociodémographiques et des problèmes de santé mentale en fonction du GT et du GI au prétest $(N=193)$

\begin{tabular}{lccccc}
\hline & GT $(\mathrm{n}=95)$ & & GI $(\mathrm{n}=98)$ & \multirow{2}{*}{$\chi^{2}$} \\
\cline { 2 - 5 } & Fréquence & $\%$ & Fréquence & $\%$ & \\
\hline Genre & & & & & 13,88 \\
$\quad$ Masculin & 61 & 64 & 65 & 66 & - \\
$\quad$ Féminin & 34 & 36 & 33 & 33 & - \\
Niveau d'éducation & & & & 16,26 \\
$\quad$ Terminé ou entrepris des études & 15 & 16 & 22 & 22 & - \\
$\quad$ postsecondaires & & & & & \\
$\quad$ Études secondaires terminées & 24 & 25 & 21 & 21 & - \\
$\quad$ Études secondaires non complétées & 56 & 59 & 55 & 55 & - \\
Problèmes de santé mentale & & & & & \\
Dépression & 72 & 76 & 64 & 65 & 2,87 \\
ÉSPT & 46 & 48 & 43 & 43 & 0,49 \\
Trouble psychotique & 22 & 23 & 22 & 22 & 0,02 \\
Idées suicidaires & & & & & $8,68^{*}$ \\
$\quad$ Aucun & 7 & 7 & 9 & 9 & - \\
$\quad$ Faible & 37 & 39 & 34 & 34 & - \\
$\quad$ Modéré & 16 & 17 & 33 & 33 & - \\
$\quad$ Élevé & 35 & 37 & 23 & 23 & - \\
Dépendance & & & & & \\
Alcool & 30 & 32 & 21 & 31 & 0,00 \\
Drogues & 49 & 52 & 55 & 56 & 0,31 \\
\hline
\end{tabular}

$\mathrm{GT}=$ Groupe témoin; $\mathrm{GI}=$ Groupe intervention; ÉSPT = État de stress post-traumatique;

$*=p<0,05$

Le modèle de soins ACT suppose que les usagers et usagères des services ont accès à une équipe clinique multidisciplinaire en tout temps et selon leurs besoins. Le nombre d'usagers et usagères par intervenant ou intervenante est habituellement de 10. À Moncton, cette équipe était composée de deux psychiatres, d'un coordonnateur des services administratifs, d'une ergothérapeute, d'une infirmière, d'une aide familiale, d'intervenants sociaux, d'un coordonnateur des services aux usagers, d'une infirmière clinicienne, d'un coordonnateur des services d'employabilité, ainsi que d'un spécialiste du soutien par les pairs. Le ratio usagers/intervenant était de 10:1. Pour leur part, les personnes qui ont été assignées au groupe témoin ont bénéficié des services et programmes préexistants de la région, c'est-à-dire les refuges, les services de toxicomanie, les services de santé et les services sociaux. Ces participants et participantes pouvaient recevoir des 
services de soutien au logement et des services de soutien communautaires sans toutefois que cela fasse partie du programme Logement d'abord.

\section{Instruments}

Les instruments de mesure utilisés dans la présente étude sont adaptés d'échelles déjà validées (Macnaughton, Goering et Nelson, 2012). Les propriétés psychométriques des instruments utilisés s'avèrent adéquates (Goering et al., 2011). Les variables démographiques incluent l'âge, le sexe et le niveau d'éducation (primaire, secondaire non complété, secondaire, postsecondaire).

Le Mini International Neuropsychiatric Interview 6.0 (MINI) (Lecrubier et al., 1997) a été utilisé pour décrire l'état psychiatrique des participants et participantes au point d'entrée à l'étude. Des assistants et assistantes de recherche qui ont reçu une formation préalable sur les instruments utilisés aux fins de l'étude ont administré le MINI. L'absence ou la présence d'un diagnostic a servi à établir la prévalence des troubles psychiatriques au sein de l'échantillon.

Le Health Service Access Items (ACC) (Hwang et al., 2010) évalue l'accès aux services de santé à l'aide de trois items et inclut les services suivants : médecin de famille et endroit pour consultation ou service de soins au besoin comme les cliniques de santé communautaires. Le cumul des réponses positives compose la mesure de l'accès aux services de santé dans la présente étude, un score élevé indiquant un meilleur accès.

Le Comorbid Conditions Questionnaire (CMC) sert à identifier les problèmes de santé physique et les maladies chroniques des participants et participantes. Plus précisément, le CMC permet de déterminer la présence ou l'absence de problèmes de santé particuliers. Le CMC comprend des éléments provenant d'instruments similaires : l'Enquête sur la santé dans les collectivités canadiennes (Statistique Canada, 2014), l'Enquête nationale sur la santé de la population (Statistique Canada, 2012) et d'autres outils (Mares et Rosenheck, 2007). Le score à cet instrument représente le cumul du nombre de problèmes de santé physique et de maladies chroniques (comme le diabète, l'asthme ou l'arthrite). L'Index de sévérité de l'itinérance (ISI) correspond au nombre de mois d'itinérance au total pendant la vie des participants et participantes (Dickey, Latimer, Powers, Gonzalez et Goldfinger, 1997) et a servi de mesure de la sévérité de l'itinérance.

Quatre mesures du recours aux services de santé ont servi de variables dépendantes. Les quatre variables dépendantes incluent le recours aux services suivants : services hospitaliers ambulatoires (SHA), salles d'urgence (SU), hospitalisations (HOS) et hospitalisations à l'unité psychiatrique (HOS-P). Le recours aux SHA est mesuré par le nombre de fois que la personne a utilisé les services hospitaliers ambulatoires au cours des 6 derniers mois sans y être demeurée la nuit et exclut les visites aux salles d'urgence et les visites pour des tests de routine. Le recours aux SU représente le nombre de fois que les participants et participantes ont utilisé ces services au cours des 6 derniers mois. Les HOS comprennent le nombre de jours qu'une personne a été hospitalisée au cours des 6 derniers mois et les HOS-P correspondent au nombre de jours qu'un patient a été hospitalisé à l'unité psychiatrique d'un hôpital au cours des 6 derniers mois. 


\section{Procédure}

L'approbation éthique du centre hospitalier universitaire et du centre national de coordination du projet At Home / Chez Soi fut obtenue (Goering et al., 2011). A également été obtenue l'approbation éthique des universités et des établissements de santé où travaillent les chercheurs impliqués dans les cinq sites de démonstration. Le projet At Home / Chez Soi est inscrit à l'International Standard Randomised Control Trial Number Register et est identifié par le numéro ISRCIN42520374.

Des équipes de recherche dans chacun des cinq sites du projet ont administré les instruments de mesure aux participants et participantes sur une période de 2 ans. La plateforme Health Diary a servi à l'encodage et à l'entreposage des données (Goering et al., 2011). La présente étude s'attarde uniquement aux données du site de Moncton obtenues lors d'entrevues de suivi au prétest et à intervalles de 6 mois, 12 mois, 18 mois et 24 mois.

Les participantes et participants ont été recrutés tout d'abord dans des refuges et dans des centres de santé mentale de la ville de Moncton. Une ligne téléphonique sans frais a également été utilisée afin que les individus puissent s'autoréférer. Des organismes communautaires et les services de santé mentale de la région de Moncton pouvaient aussi référer des participants et participantes au projet. Les membres de l'équipe de recherche ont ensuite rencontré les participants et participantes dans des refuges, dans des hôpitaux ou dans des lieux publics offrant un certain niveau de tranquillité. Pour ce qui est des participants et participantes qui vivaient provisoirement dans la communauté, ceux-ci ont été rencontrés dans leur logement afin de leur présenter le projet At Home / Chez Soi. Le consentement de ceux qui désiraient participer a été obtenu et une évaluation de leur admissibilité a été effectuée.

Les membres de l'équipe de recherche ont suivi une formation spécifique sur le protocole du projet et pour l'administration des questionnaires afin de normaliser la collecte de données. Les critères d'inclusion à l'étude sont les suivants : être âgé de 18 ans ou plus, être sans logement ou précairement logé, c'est-à-dire dans une chambre individuelle, dans une maison de chambres, dans un hôtel ou dans un motel et être atteint d'un trouble sévère de santé mentale selon l'évaluation du MINI, qui ciblait tout particulièrement les troubles de l'axe I du DSM-IV (American Psychiatric Association, 1994).

Un membre de l'équipe a ensuite rencontré les candidats admissibles et consentants afin de leur administrer les questionnaires du prétest. Les participants et participantes admissibles ont ensuite été répartis aléatoirement entre le groupe intervention et le groupe témoin selon un ratio 1:1 (Aubry, Bourque et al., 2014). Cette répartition en groupes a été déterminée par le service d'encodage des données en utilisant un algorithme adapté, et le résultat a été révélé aux participants et participantes à la fin de l'entrevue. Les participants et participantes et ceux qui administraient les entrevues n'étaient donc pas aveugles à la composition des groupes. Les participantes et participants se sont engagés à répondre à ces mêmes questionnaires tous les 6 mois pour la durée de leur participation, c'est-à-dire à $6,12,18$ et 24 mois. Les questions étaient lues à tous les participants et participantes afin de normaliser l'administration des questionnaires. Une légère indemnisation financière fut offerte en remerciement de leur participation. Les détails concernant le protocole du projet At Home / Chez Soi sont présentés dans Goering et al. (2011). 


\section{Analyses statistiques}

Dans le cadre de cette étude, des comparaisons entre la progression dans le temps du groupe témoin et du groupe intervention ont été effectuées pour l'ensemble des variables à l'étude à l'aide d'analyses de variance à modèle mixte sur chacune des variables de recours aux services, soit les SHA, les SU, les HOS et les HOS-P. Une variable muette (Event) a été créée pour identifier les cinq temps de mesure alors que le groupe d'appartenance (témoin ou intervention) constituait la variable indépendante (Group) dans les quatre modèles. Une attention particulière a été portée à l'effet d'interaction Event x Group pour déterminer si la progression de l'utilisation des quatre différents types de services dans le temps différait selon le groupe. Puisque l'ensemble des variables dépendantes s'est avéré fortement asymétrique avec un mode à zéro, une distribution négative binomiale a été postulée. Les analyses statistiques ont été effectuées à l'aide de la $22^{\mathrm{e}}$ version du logiciel Statistical Package for the Social Sciences (SPSS). Toutes les analyses ont été faites selon l'intention de traitement (intent to treat), c'est-à-dire que chaque unité statistique a été analysée selon le groupe auquel elle a été randomisée.

\section{RÉSULTATS}

Le profil des variables sociodémographiques et des problèmes de santé mentale est présenté au tableau 1. Les résultats de la présente recherche démontrent qu'il n'y a aucune différence statistiquement significative entre les deux groupes pour ce qui est des problèmes de santé mentale, sauf pour la variable idées suicidaires, $\chi^{2}(3)=8,68, p<0,05$. Les résidus standardisés ajustés indiquent que le groupe témoin présente un taux d'idées suicidaires plus élevé que le groupe intervention. De plus, au tableau 2, les résultats ne démontrent pas de différences statistiquement significatives entre le groupe témoin et le groupe intervention quant à l'accès aux services, aux maladies chroniques et à la sévérité de l'itinérance. De façon générale, les résultats ne révèlent pas de différences entre le groupe témoin et le groupe intervention pour ce qui est des variables sociodémographiques et de santé. Ces résultats confirment que la répartition de l'échantillonnage s'avère équivalente pour les deux groupes en ce qui a trait à la plupart des variables mesurées.

suite à la page 26

\section{Tableau 2}

Moyennes, écarts-types et test- $t$ des variables de l'état de santé au prétest pour le groupe témoin et le groupe intervention $(N=193)$

\begin{tabular}{lccccc}
\hline & \multicolumn{2}{c}{ Groupe témoin } & \multicolumn{2}{c}{ Groupe intervention } & \multirow{2}{*}{$*$} \\
\cline { 2 - 4 } & Moyennes & ÉT & Moyennes & ÉT & \\
\hline & 1,96 & 0,76 & 1,98 & 0,88 & $-0,19$ \\
Accès aux services (ACC) & 6,00 & 3,35 & 5,62 & 3,40 & 0,78 \\
Maladies chroniques (CMC) & 41,74 & 49,52 & 57,85 & 85,93 & 1,57 \\
Sévérité de l'itinérance (ISI) & & & & & \\
\hline
\end{tabular}



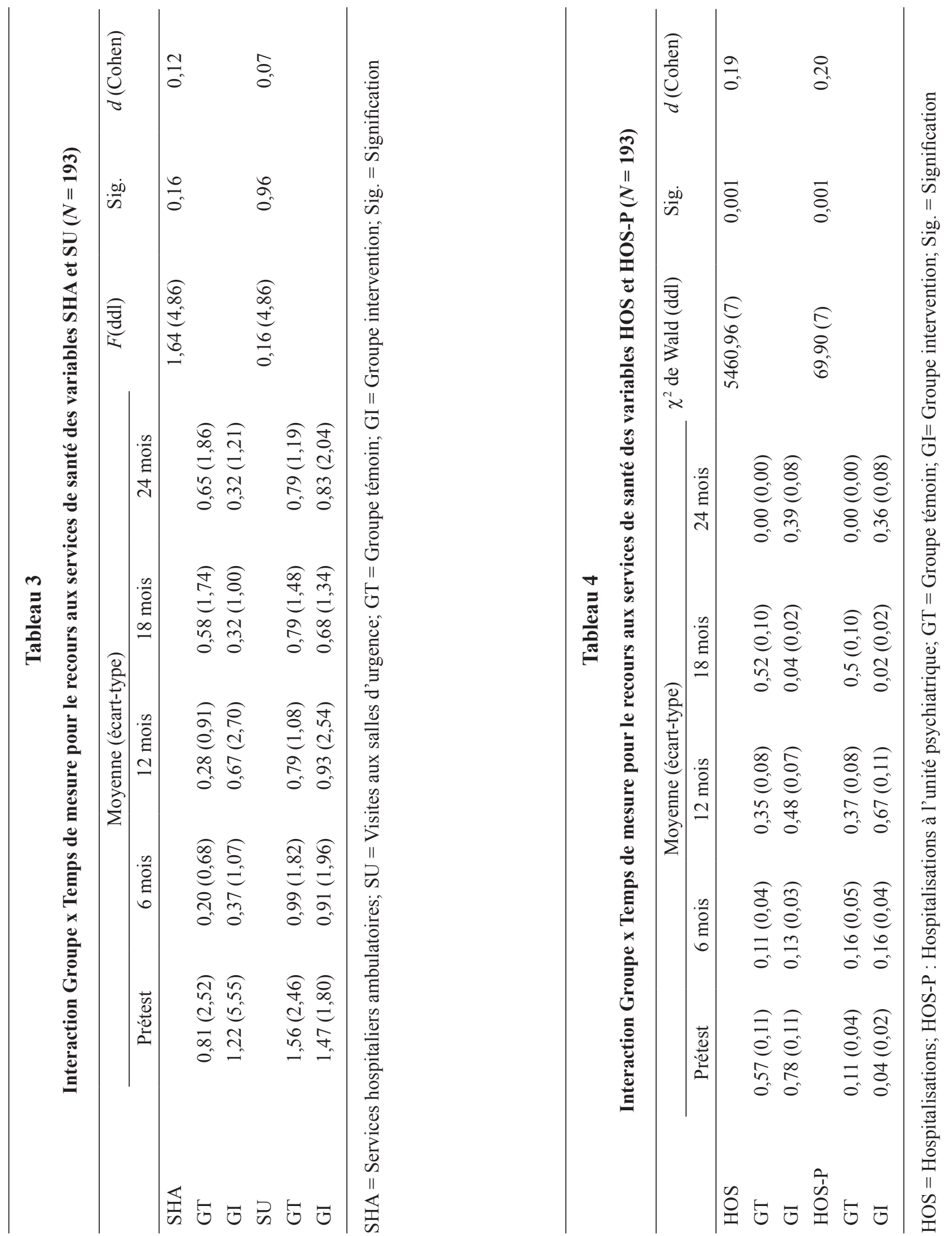


\section{Figure 1}

Moyennes du recours aux services de santé en fonction du temps $(N=193)$
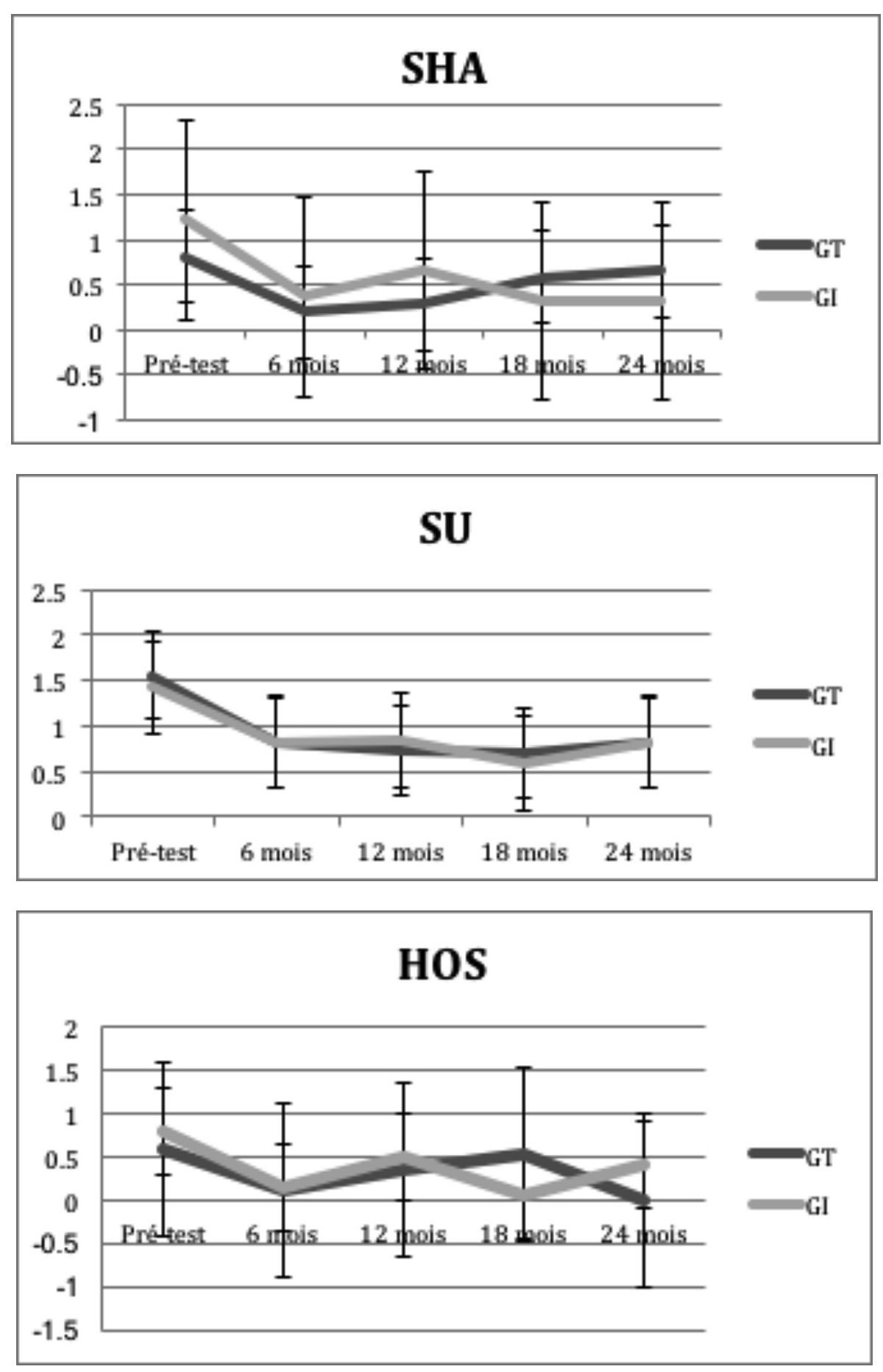
Figure 1, suite

Moyennes du recours aux services de santé en fonction du temps $(N=193)$

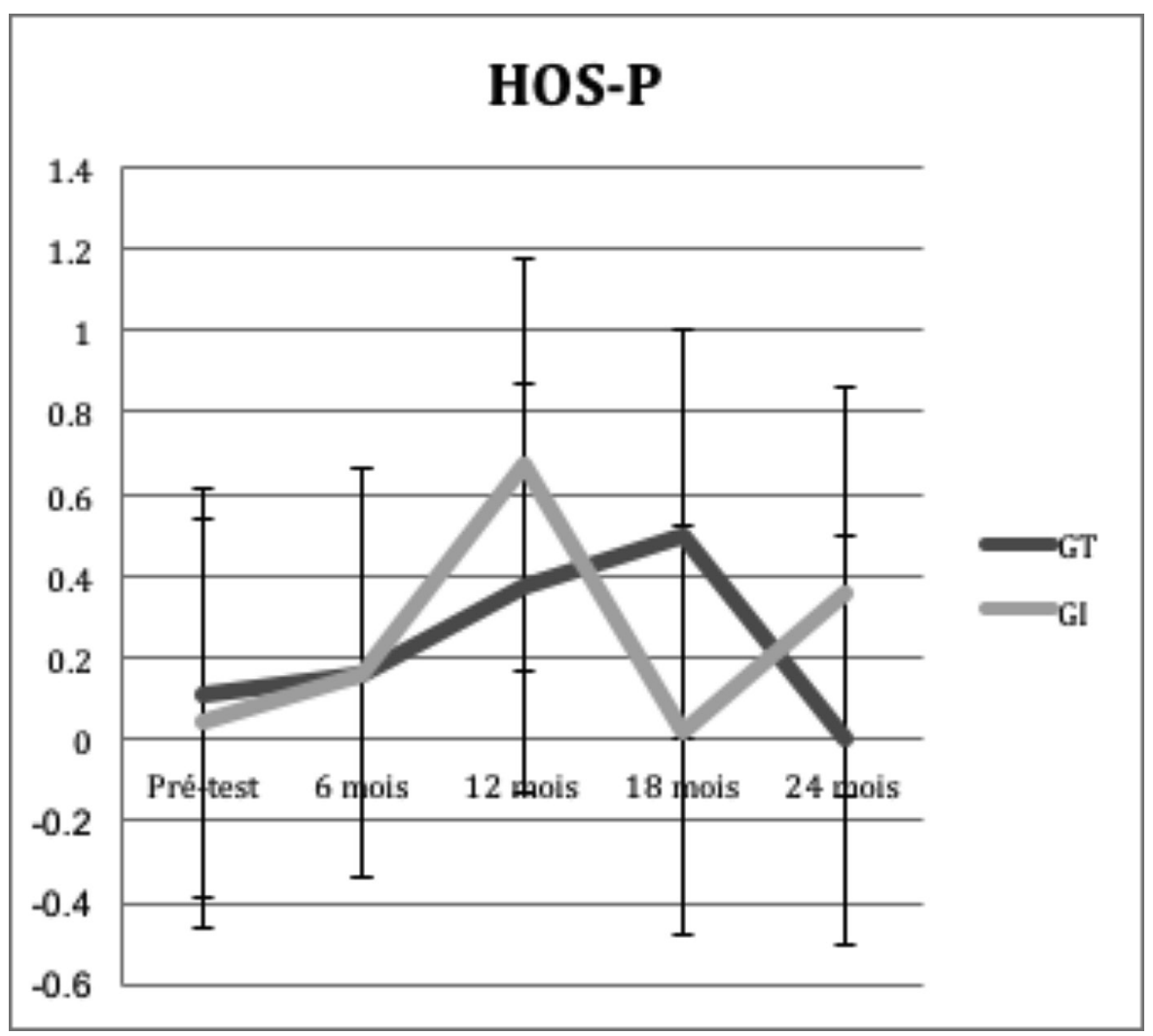

$\mathrm{SHA}=$ Services hospitaliers ambulatoires; $\mathrm{SU}=$ Visites aux salles d'urgence; HOS = Hospitalisations; HOS-P : Hospitalisations à l'unité psychiatrique; GT = Groupe témoin; GI= Groupe intervention 


\section{suite de la page 22}

Les tableaux 3 et 4 ainsi que la figure 1 présentent les résultats de l'analyse de variance à modèle mixte pour le recours aux services de santé entre les groupes en fonction du temps. Ces résultats ne révèlent pas de différences statistiquement significatives pour ce qui est du recours aux SHA et aux SU entre les groupes en fonction du temps. Les tailles d'effet, toutes inférieures à 0,20 en valeur absolue, sont négligeables selon le critère de Cohen (1988). Par contre, les résultats révèlent une interaction significative entre le groupe et le temps pour ce qui est du nombre de jours d'hospitalisation et du nombre de jours d'hospitalisation à l'unité psychiatrique. En effet, comme le montre le tableau 4, la variation dans le temps des nombres de jours d'hospitalisation et d'hospitalisation à l'unité psychiatrique diffère entre les deux groupes, avec une diminution plus prononcée après 24 mois chez le groupe intervention.

\section{DISCUSSION}

La présente étude évaluait, dans le cadre du projet At Home / Chez Soi, l'impact d'une intervention Logement d'abord sur le recours aux services hospitaliers ambulatoires, les visites aux salles d'urgence, les hospitalisations et les hospitalisations à l'unité psychiatrique par des personnes itinérantes de la région de Moncton ayant des problèmes sévères et chroniques de santé mentale. À cet égard, les résultats révèlent que l'intervention Logement d'abord n'a pas eu d'incidence sur le recours aux services hospitaliers ambulatoires et les visites aux salles d'urgence. En effet, au cours des 24 mois de suivi du projet, le recours à ces services a diminué, mais de façon équivalente pour le groupe témoin et pour le groupe intervention. Par contre, le groupe intervention et le groupe témoin présentent une trajectoire temporelle différente quant au taux d'hospitalisation à l'unité psychiatrique, qui se conclut avec une fréquentation moindre pour le groupe intervention à 24 mois.

Ces résultats ne concordent pas avec ceux de Kessell, Bhatia, Bamberger et Kushel (2006), qui n'ont noté aucun changement dans le recours aux services de santé entre un groupe intervention avec logement et un groupe témoin. Cependant, comme l'ont noté ces mêmes auteurs, les taux de recours aux services de santé sont élevés, à l'instar des résultats de la présente étude. Il est possible que la nature du suivi intensif dans le milieu puisse expliquer ces résultats. Plus particulièrement, le fait que les participants et participantes dans le groupe intervention reçoivent un suivi communautaire d'une équipe multidisciplinaire qui les soutient durant des périodes difficiles sert à prévenir les hospitalisations. Ces résultats correspondent aux résultats provenant d'un grand nombre d'études sur les équipes communautaires des traitements intensifs (Aubry, Dostaler et Baronet, 2004).

Malgré les effets négligeables observés, la présente étude sert tout de même à documenter le recours aux services de santé par les personnes itinérantes ayant des problèmes sévères et chroniques de santé mentale. Tel qu'on l'a observé dans les études de Mares et Rosenheck (2010) et de Wright, Vartanian, Hsin-Fang, Royal et Matson (2016), le recours aux services diminue après participation à l'intervention. Cependant, ces deux études ne comprenaient pas de groupe témoin. Dans une autre étude (Martinez et Burt, 2006), l'intervention avec logement réduit le recours aux salles d'urgence et les taux d'hospitalisation pour les personnes itinérantes. Or, dans la présente étude, le recours aux services a diminué de façon similaire pour les groupes témoin et intervention seulement pour les services hospitaliers ambulatoires et les visites aux 
salles d'urgence. Donc, il semble y avoir un effet différentiel plutôt en fonction de la nature du suivi intensif dans le milieu et de la durée de l'intervention.

D'ailleurs, les caractéristiques des personnes itinérantes de la région de Moncton indiquent que ce sont surtout les personnes souffrant d'un état de stress post-traumatique qui ont moins recours aux services hospitaliers ambulatoires par rapport aux personnes itinérantes présentant un autre diagnostic (Pakzad et al., 2015). De plus, les femmes utilisent plutôt les services sociaux et communautaires. Il est possible que les participantes et participants de la présente étude aient été référés au programme durant une période difficile de leur vie et nous pouvons prévoir qu'ils vont s'améliorer et retourner à un fonctionnement plus stable avec le temps.

L'écart entre les résultats de la présente étude et ceux de Martinez et Burt (2006) peut être expliqué par le fait que ces derniers ont utilisé les données administratives provenant des dossiers médicaux plutôt que des données autorapportées. Il est à noter que le site de Moncton avait au départ une plus faible utilisation des services de santé que les autres sites du projet At Home / Chez Soi (Aubry, Bourque et al., 2014). La rareté en comparaison avec les autres grandes villes participant à l'étude et la difficulté d'accès aux services disponibles pour cette population pourraient être en cause. Les personnes itinérantes ont très peu recours aux services de santé mentale, ce qui laisse supposer que la priorité est plutôt dirigée vers la santé physique que vers la santé mentale (Bhui et al., 2006).

Certaines limites inhérentes à la présente étude méritent d'être soulignées. Premièrement, la taille de l'échantillon est modeste compte tenu du modèle utilisé. De plus, il ne représente pas nécessairement les autres régions rurales ou métropolitaines du pays. Cependant, il existe peu d'articles scientifiques qui traitent de programmes de logement dans des villes de petite taille. La présente étude pourrait éventuellement être incluse dans une méta-analyse pour contribuer à évaluer l'effet de telles interventions. De plus, aucune information du dossier médical des participants et participantes permettant de vérifier la durée et le nombre des recours aux services hospitaliers et d'urgence n'était accessible.

\section{CONCLUSION}

Les résultats de la présente étude soulèvent certains constats quant au recours aux services de santé par les personnes itinérantes. Afin de mieux comprendre ces résultats, des analyses plus approfondies avec des données administratives s'imposent et permettraient de mieux identifier les facteurs associés au recours aux services de santé par les personnes itinérantes. Cependant, les personnes itinérantes ont davantage recours aux services sociaux et communautaires qu'aux services spécialisés en santé mentale (Bhui et al., 2006). Il serait important de mieux cerner les raisons, les attitudes et les obstacles influençant le recours des personnes itinérantes aux services de santé mentale.

\section{RÉFÉRENCES}

American Psychiatric Association. (1994). Diagnostic and statistical manual of mental disorders (4éd.). Washington, DC : Author.

Aubry, T., Bourque, J., Volk, J., Leblanc, S., Nolin, D. et Jetté, J. (2014). Projet Chez Soi : rapport final du site de Moncton. Calgary, AB : Commission de la santé mentale du Canada. 
Aubry, T., Dostaler, T. et Baronet, A.-M. (2004). Revue des études empiriques sur l'efficacité du suivi communautaire. Dans R. Emard et T. Aubry (dir.), Le suivi communautaire en santé mentale : une invitation à bâtir sa vie (p. 129-202). Ottawa, ON : Presses de l'Université d'Ottawa.

Aubry, T., Ecker, J. et Jetté, J. (2014). Supported housing as a promising Housing First approach for people with severe and persistent mental illness. Dans M. Guirgis-Younger, R. McNeil et S. W. Hwang (dir.), Homelessness \& health in Canada (p. 155-188). Ottawa, ON : Presses de l'Université d'Ottawa.

Aubry, T., Klodawsky, F. et Coulombe, D. (2012). Comparing the housing trajectories of different classes within a diverse homeless population. American Journal of Community Psychology, 49(1-2), 142-155.

Baggett, T. P., Hwang, S. W., O’Connell, J. J., Porneala, B. C., Stringfellow, E. J., Orav, E. J., [. . .] Rigotti, N. A. (2013). Mortality among homeless adults in Boston: Shifts in causes of death over a 15-year period. JAMA Internal Medicine, 173, 189-195.

Baggett, T. P., O’Connell, J. J., Singer, D. E. et Rigotti, N. A. (2010). The unmet health care needs of homeless adults: A national study. American Journal of Public Health, 100, 1326-1333.

Bhui, K., Shanahan, L. et Harding, G. (2006). Homelessness and mental illness: A literature review and a qualitative study of perceptions of the adequacy of care. International Journal of Social Psychiatry, 52(2), 152-165.

Cohen, J. (1988). Statistical power analysis for the behavioral sciences (2 éd.). Hillsdale, NJ: Lawrence Erlbaum Associates.

Culhane, D. P., Metraux, S. et Hadley, T. (2002). Public service reductions associated with placement of homeless persons with severe mental illness in supportive housing. Housing Policy Debate, 13(1), 107-163.

Dickey, B., Latimer, E., Powers, K., Gonzalez, O. et Goldfinger, S. M. (1997). Housing costs for adults who are mentally ill and formerly homeless. Journal of Mental Health Administration, 24(3), 291-305.

Forchuk, C., Brown, S. A., Schofield, R. et Jensen, E. (2008). Perception of health and health service utilization among homeless and housed psychiatric consumers/survivors. Journal of Psychiatric and Mental Health Nursing, 15(5), 399-407.

Goering, P. N., Streiner, D. L., Adair, C., Aubry, T., Barker, J., Distasio, J. et Zabkiewicz, D. M. (2011). The At Home / Chez Soi trial protocol: A pragmatic, multi-site, randomized controlled trial of a Housing First intervention for homeless individuals with mental illness in five Canadian cities. British Medical Journal Open, 1(2). doi:10.1136/bmjopen-2011-000323

Goering, P., Veldhuizen, S., Watson, A., Adair, C., Kopp, B., Latimer, E. et Aubry, T. (2014). Rapport final du projet pancanadien Chez Soi. Calgary, AB : Commission de la santé mentale du Canada.

Groton, D. (2013). Are Housing First programs effective? A research note. Journal of Sociology and Social Welfare, $40(1), 51-63$.

Gulcur, L., Stefancic, A., Shinn, M., Tsemberis, S. et Fischer, S. N. (2003). Housing, hospitalization, and cost outcomes for homeless individuals with psychiatric disabilities participating in continuum of care and Housing First programmes. Journal of Community \& Applied Social Psychology, 13(2), 171-186.

Hahm, H. C. et Segal, S. P. (2005). Failure to seek health care among the mentally ill. American Journal of Orthopsychiatry, 75(1), 54-62.

Hwang, S. W., Aubry, T., Palepu, A., Farrell, S., Nisenbaum, R., Hubley, A. et Chambers, C. (2011). The health and housing in transition study: A longitudinal study of the health of homeless and vulnerably housed adults in three Canadian cities. International Journal of Public Health, 56, 609-623.

Hwang, S. W., Chambers, C., Chiu, S., Katic, M., Kiss, A., Redelmeier, D. A. et Levinson, W. (2013). A comprehensive assessment of health care utilization among homeless adults under a system of universal health insurance. American Journal of Public Health, 103(Suppl. 2), S294-S301.

Hwang, S. W., Ueng, J. J., Chiu, S., Kiss, A., Tolomiczenko, G., Cowan, L., [. . .] Redelmeier, D. A. (2010). Universal health insurance and health care access for homeless persons. American Journal of Public Health, 100(8), 1454-1461.

Kessell, E. R., Bhatia, R., Bamberger, J. D. et Kushel, M. B. (2006). Public health care utilization in a cohort of homeless adult applicants to a supportive housing program. Journal of Urban Health, 83(5), 860-873.

Lecrubier, Y., Sheehan, D.V., Weiller, E., Amorim, P., Bonora, I., Sheehan K, [. . .] Dunbar, G. (1997). The Mini International Neuropsychiatric Interview (MINI): A short diagnostic structured interview: Reliability and validity according to the CIDI. European Psychiatry, 12(5), 224-231. 
Leff, H. S., Chow, C. M., Pepin, R., Conley, J., Allen, I. E. et Seaman, C. A. (2009). Does one size fit all? What we can and can't learn from a meta-analysis of housing models for persons with mental illness. Psychiatric Services, 60, 473-482,

Macnaughton, E. L., Goering, P. N. et Nelson, G. B. (2012). Exploring the value of mixed methods within the At Home / Chez Soi Housing First project: A strategy to evaluate the implementation of a complex population health intervention for people with mental illness who have been homeless. Revue canadienne de santé publique, 103(7 Suppl. 1), S57-S62.

Mares, A. S. et Rosenheck, R. A. (2007). HUD/HHS/VA collaborative initiative to help end chronic homelessness national performance outcomes assessment: Preliminary client outcomes report. West Haven, CT : Northeast Program Evaluation Center.

Mares, A. S. et Rosenheck, R. A. (2010). Twelve-month client outcomes and service use in a multisite project for chronically homeless adults. Journal of Behavioral Services \& Research, 37(2), 167-183.

Mares, A. S. et Rosenheck, R. A. (2011). A comparison of treatment outcomes among chronically homelessness adults receiving comprehensive housing and health care services versus usual local care. Administration and Policy in Mental Health and Mental Health Services Research, 38(6), 459-475.

Martinez, T. et Burt, M. (2006). Impact of permanent supportive housing on the use of acute care health services by homeless adults. Psychiatric Services, 57(7), 992-999.

Nelson. (2010). Housing for people with serious mental illness: Approaches, evidence, and transformative change. Journal of Sociology and Social Welfare, 37(4), 123-146.

Nelson, G., Aubry, T. et Lafrance, A. (2007). A review of the literature on the effectiveness of housing and support, Assertive Community Treatment, and intensive case management interventions for persons with mental illness who have been homeless. American Journal of Orthopsychiatry, 77(3), 350-361.

Nusselder, W. J., Marcel, T., Slockers, M. T., Krol, K., Slockers, C. T., Looman, C. W. N. et van Beeck, E. F. (2013). Mortality and life expectancy in homeless men and women in Rotterdam: 2001-2010. PLOS ONE, 8(10): e73979.

O’Connell, M. J., Kasprow, W. et Rosenheck, R. A. (2008). Rates and risk factors for homelessness after successful housing in a sample of formerly homeless veterans. Psychiatric Services, 59, 268-275.

Pakzad, S., Bergheul, S., Jbilou, J., Bourque, J., Ringuette, J., Gallant, L. et Bourque, P. E. (2015). Le recours aux services de santé, sociaux et communautaires par les personnes itinérantes de la région de Moncton. Revue canadienne de santé mentale communautaire, 33(4), 91-105.

Rog, D. J., Marshall, T., Dougherty, R. H., George, P., Daniels, A. S., Ghose, S. S. et Delphin-Rittmon, M. E. (2014). Permanent supportive housing: Assessing the evidence. Psychiatric Services, 65(3), 287-294.

Statistique Canada. (2012). Enquête nationale sur la santé de la population : volet ménages, longitudinal (ENSP). Récupéré de http://www23.statcan.gc.ca/imdb/p2SV_f.pl?Function=getSurvey\&SDDS=3225

Statistique Canada. (2014). Enquête sur la santé dans les collectivités canadiennes-composante annuelle (ESCC). Récupéré de http://www23.statcan.gc.ca/imdb/p2SV_f.pl?Function=getSurvey\&SDDS=3226

Tsemberis, S. (2010). Housing First: The pathways model to end homelessness for people with mental illness and addiction. Center City, MN: Hazelden.

Wright, B. J., Vartanian, K. B., Hsin-Fang, L. Royal, N. et Matson, J. K, (2016). Formerly homeless people had lower overall health care expenditures after moving into supportive housing. Health Affairs, 35, 20-27. 